\title{
From service for free to service for fee: business model innovation in manufacturing firms
}

\author{
Lars Witell and Martin Löfgren
}

\section{Linköping University Post Print}

\section{Tweet}

N.B.: When citing this work, cite the original article.

Original Publication:

Lars Witell and Martin Löfgren, From service for free to service for fee: business model innovation in manufacturing firms, 2013, Journal of Service Management, (24), 5, 520-533. http://dx.doi.org/10.1108/JOSM-04-2013-0103

Copyright: Emerald http://www.emeraldinsight.com/

Postprint available at: Linköping University Electronic Press

http://urn.kb.se/resolve?urn=urn:nbn:se:liu:diva-103327 


\title{
From Service for Free to Service for Fee: Business model innovation in manufacturing firms
}

\author{
Lars Witell $^{1,2}$ and Martin Löfgren ${ }^{1}$
}

1. CTF, Service Research Center, Karlstad University, Sweden

2. IEI-Industrial Engineering and Management, Linköping University, Sweden

\section{Abstract \\ Purpose}

The purpose of the present research is to identify how business model innovation can be used to make the transition from service for free to service for fee. In particular, the focus is on identifying, describing and analysing alternative transition strategies, degree and type of innovation, and how building blocks in the business model change.

\section{Design/methodology/approach}

A multiple case study of six manufacturing firms was performed. Data was collected through interviews with CEOs, service managers and sales managers. In addition, two workshops were performed with the participating firms.

\section{Findings}

The present research identified eight strategies for transitioning from service for free to service for fee. These strategies represent change in the business model, incremental business model innovation and radical business model innovation. It is suggested to change the content and structure to perform incremental business model innovation and change the governance to perform radical business model innovation.

\section{Originality/value}

In most models for service infusion, the change of business model is seen as a necessary step and focus is placed on that a change of business model is needed. The present study elaborates on what approaches manufacturing firms use to make the change from one business model to another.

Keywords: Service infusion, business model innovation, value proposition, manufacturing firms

Classification: Research paper 


\section{Introduction}

Many manufacturing firms infuse services in the value proposition to create a competitive advantage (Gebauer et al., 2010; Neu and Brown, 2005; Oliva and Kallenberg, 2003). This process is often referred to as service infusion (Gustafsson et al., 2010), suggesting that services are becoming a greater part of offerings and influence the organisation of manufacturing firms (Gebauer et al., 2010). But, focusing on technology, products and the value of exchange gave rise to a tradition of including free services in the product sales (Oliva and Kallenberg, 2003). For manufacturing firms adding services to the value proposition, a key question is if a product-based business model is consistent with the competitive advantage of the firm. Visnjic Kastalli and van Looy (2013) show that increased service sales has a positive effect on product sales, suggesting a dual effect of charging separately for services.

In a changing business environment, business model innovation can provide a competitive advantage (Osterwalder et al., 2005; Chesbrough, 2010). Because many manufacturing firms do not charge separately for services and view them solely as cost drivers, service infusion calls for new business models, suggesting a change from service for free to service for fee. However, a fundamental problem is that customers are often not prepared to start paying for something that they used to get for free (Brown et al., 2010). A change in just the revenue streams might not be enough, changing several building blocks in the business model might be needed (Osterwalder and Pigneur, 2010). In particular, business model innovation can be used to change the content (adding novel activities), structure (linking activities in novel ways) or governance (changing one or more parties that perform any of the activities) of the business model (Amit and Zott, 2012). A recent study suggests that governance, i.e. 
finding the right value constellation for service provision is a key for service infusion in practice (see e.g. Kowalkowski et al., 2013).

The purpose of the present research is to identify how business model innovation can be used to make the transition from service for free to service for fee. In particular, the focus is on identifying, describing and analysing alternative transition strategies, degree and type of innovation, and how building blocks in the business model change. A multiple case study of six manufacturing firms was performed to identify and describe services where the business model had been changed from free to fee. The results provide a range of transition strategies to pursue changes in the business model, incremental business model innovation and radical business model innovation. The transition strategies from free to fee can aid a manufacturing firm to increase the service revenues when infusing services in their business.

\section{Theoretical Framework}

Most research described service infusion as a strategy that manufacturing firms use to improve profits in highly competitive industries (Fang et al., 2008; Neely, 2008). However, service infusion is not a certain way to profitability (Krishnamurthy et al., 2003). The decision to infuse service in the business influence profitability, while the extent of service infusion has a negative effect (Neely, 2008). The positive results of service infusion reappear only when the extent of service infusion achieves a critical mass (Fang et al., 2008). But, the results of Visnjic Kastalli and van Looy (2013) suggest that a transition strategy from service for free to service for fee could have an indirect effect on the sales of products. 
Innovation of products in manufacturing firms is often based on the development of new technology. As a result, innovations are often designed to improve product or service performance, rather than to improve value co-creation with a specific customer (Gustafsson et al., 2010; Hsu, 2011). However, what makes a service innovative is often not the service per se, but the changing roles of customers, service providers and partners in the value network (Ostrom et al., 2010; Gustafsson et al., 2012). New concepts and/or value propositions, new delivery mechanisms and/or business models are areas for service innovation (Wooden and Baker, 2012). Consequently, business model innovation is important in understanding how to make service infusion in manufacturing firms profitable and how to turn service for free into service for fee.

\section{Business model innovation and the value proposition}

Most manufacturing firms successfully use a business model in which the product is the price carrier and services are seen as a cost. The business model should explain how the firm make a profit from its operations (Nenonen and Storbacka, 2010). Following Chesbrough (2007), a business model has two important roles: value creation and value capture. A business model has been defined as "a conceptual tool that contains a set of elements and their relationships and allows expressing the business logic of a specific firm. It is a description of the value a company offers to one or several segments of customers and of the architecture of the firm and its network of partners for creating, marketing, and delivering this value and relationship capital, to generate profitable and sustainable revenue streams" (Osterwalder et al., 2005, p. 10). Osterwalder and Pigneur (2010) present a business model canvas consisting of key partners, key activities, key resources, cost structure, value proposition, customer relationships, channels, revenue streams and customer 
segments. In addition, they suggest that business models must change over time as manufacturing firms are exposed to market turbulence (Teece, 2010; Osterwalder et al., 2005). The present research has its starting point in service infusion as a driving force for change in the business logic of a manufacturing firm. A change in the business logic calls for changes in the business model (Grönroos and Helle, 2010).

The novelty of a business model can be created by changing 'the structure, content, and governance of transactions' between the manufacturing firm, their partners and customers (Zott and Amit, 2010). Innovating the content of the business model involves adding novel activities through forward or backward integration. Innovating the structure of the business model involves linking activities in novel ways. Changing one or more parties that perform any of the activities is referred to as innovating the governance of the business model.

The literature review provides us with a conceptual model for analysing the change that manufacturing firms pursue when transitioning from free service to fee service. This represents a change in the revenue streams, but to successfully build a service business only changing the revenue streams of the business model might not be enough. In the present research, focus is placed on different approaches to the change in business model and what building blocks of the business model that need to change to innovate the business model.

\section{Research Methodology}

This research emphasises the identification, description and analysis of alternative strategies that manufacturing firms use for business model innovation. Through industry contacts, cases were identified in which manufacturing firms either began to 
charge for services that previously were free or created new business models for new services.

\section{A multiple case study}

To gain in-depth knowledge on the empirical phenomenon and its dynamics, a case study approach was chosen (Eisenhardt, 1989). Studying multiple cases typically provides a stronger base for developing theory that is better grounded, more accurate and more generalizable (Yin, 1994; Eisenhardt and Graebner, 2007). The emphasis on understanding that is inherent to case study research implies a direct emphasis on extending and refining present theoretical models (Meredith, 1998) .

A multiple case study of six manufacturing firms was performed to identify and describe transition strategies used to move from service for free to service for fee. In the manufacturing firms, eight services were identified representing different transition strategies to move from free to fee. The firms represented the automotive, consumer goods, and pulp and paper industries; see Table I. Data was collected through interviews with key informants such as CEOs, service managers and sales managers. The number of interviews ranged from one to three for each firm, resulting in a total of 12 interviews. The semi-structured interview guide covered areas such as business models, innovation and how to change a business model. Each interview lasted 90 to 120 minutes, was recorded and transcribed into text.

- Insert Table I about here -

\section{Analysis of data}

Firstly, an initial reading of the interviews was conducted to gain a sense of the text as a whole. This analysis enabled the extraction of important concepts to understand the transition strategy from free to fee used for each service. Secondly, the cases were 
analysed to identify degree and type of business model innovation. Thirdly, each service was analysed guided by the building blocks of the business model canvas (Osterwalder, 2004). Special focus was placed on how the changes were put into practice in an on-going business relationship.

After the completion of the three-step analysis, an analysis model (see Table III) was developed to understand and describe different approaches to business model change and innovation. The analysis model is based on identifying the degree of innovation, type of innovation and the main changes in the building blocks of the business model to describe the different approaches. To further develop, test and validate the analysis model, two workshops were performed with the participating firms.

\section{Results}

All firms in this study provide basic, product-related services directly to their customers. To handle a market in which free service erodes products' profit margins, manufacturing firms began to charge directly for the services they provide. Some firms changed their business model for the entire range of services, whereas others are testing changes to the business model for individual services or for only new services. Based on the empirical data, eight transition strategies for breaking free from free service were identified. The next sections describe the identified transition strategies to move from free to fee, see Table II.

- Insert Table II about here - 


\section{Yesterday it was free - today it has a price!}

Mill Ltd. is a supplier in the pulp and paper industry that sells capital equipment, charges for spare parts and repair, and provides additional services for free. Given a long equipment lifecycle, the supplier has on-going business relationships with customers for more than 35 years. When the pace of investment declined, the strategy to offer free services resulted in losses since there was no new sales of equipment to cover the cost of service provision to existing customers.

When the supplier decided to put a fee on services, sales personnel who were not used to selling services were supposed to sell services to customers who were not used to buying services. The CEO of Mill Ltd. described the situation: 'If we go back only six or seven years, we did all possible things free for the customers. If you have no responsibility for these issues, you can see it as 'Yes, but we can do it because they will buy a new machine', or 'they are doing a pre-project'. We still do it sometimes as an investment or because we 'screwed up', but now we have a focus on profitability!'

Starting to put a fee on services resulted in customer rage; however, because no competitors existed in the service market, customers returned and the firm started to develop a profitable service business. Initially, the firm experienced a major loss in sales of repairs and spare parts; subsequently, sales increased slowly through increasing sales of other services.

\section{New service - new rules!}

Vehicle Ltd. is an OEM in the automotive industry and has a profitable service market consisting of repairs and spare parts. In addition to these basic services, it offers other services for free to create customer loyalty. The consequence is that services are viewed as a cost and getting (1) resources to develop new services and (2) customers 
to pay for services are difficult. If all services would change from free to fee, the supplier would end up in a fierce competition with its competitors on product price.

Vehicle Ltd. wants to grow the service market but does not want to put a fee on all services. The supplier developed advanced services based on new technology and started to charge for them when new vehicle models were introduced. The service manager describes this concept: 'If you package service together, especially new technology and services, I believe that we will be able to get paid for services'. Many of the advanced services are technology intensive, but the value proposition is built by the information and knowledge enabled by the technology.

Introducing a fee for new advanced services had no effect on the sales of products, spare parts and repairs. Customers accepted that advanced services have fees, but the market for these services grows slowly. One challenge for Vehicle Ltd. is to show the customer how the information provided by the services can be translated to better operational performance.

\section{The value of service!}

In addition to putting a fee on advanced services, Vehicle Ltd. uses 'The value of service!' strategy to start charging for educational services. Customers expect that a service such as driver training is free and often included with vehicle sales. The key to put a fee on this service was to get the customer to understand the value of it in both the first and second moments of truth (Löfgren, 2005). The first moment of truth represents showing the expected value of the service before customers use it, and then during the second moment of truth the realised value of savings for the customer is shown. The process of changing the service from free to fee occurred over several years, during which time different campaigns and coupons are used to educate customers in paying for this kind of service. 
To show the expected value of the service, customers are given vouchers for driver training. The basic logic is to use vouchers to get customers to understand that the service has value and to improve customer adoption. As part of the service, Vehicle Ltd. shows the realised savings that the driver training provides. By providing an attractive value proposition, the intention is to create word-of-mouth and be able to put a fee on all educational services.

\section{We deliver a product AND a service!}

Drink Ltd. uses unbundling of offerings as a deliberate strategy to put a fee on services. The key to this strategy is unbundling services from the value proposition and to develop individual value propositions for each service. Drink Ltd., which provides a beverage, traditionally charged only for the product and provided all services for free. However, because the competitive situation with decreased product margins, the firm began to unbundle services from its offering. This strategy has similarities to the "Yesterday it was free - today it has a price!" strategy, but it is a deliberate strategy to develop the value propositions of the unbundled services.

Each individual service has a price and a pricelist is provided for all salespersons to present to customers. However, most services are still provided for free. One of the reasons why charging for services is difficult is because Drink Ltd.'s most important competitors provide services for free and the firm is afraid that it will loose customers if it starts charging for services.

\section{We deliver a basic service AND extended services!}

Pulp Ltd., which provides capital equipment for the pulp and paper industry, also followed a strategy to unbundle services. Advanced services that previously were bundled together with a basic service were unbundled. The basic repair service had 
over the years been further developed to include advanced services to provide diagnostics of the equipment. The fee of the basic service was lowered, but the advanced services that previously were free now have a fee.

When the customer uses the basic service, Pulp Ltd. applies diagnostics to determine the need for extended services. If such services are needed, the customer is contacted with a proposal for the extended services. When introduced, this strategy started with sales of the basic service and no sales of extended services. However, after an initial period of low sales, customers began to get used to ordering and paying for extended services and the sales volume increased.

\section{You get what you pay for!}

Bearing Ltd. is a large international manufacturer of high quality products. To use the product effectively, free educational services were provided. However, the free educational services saw fewer participants and interest from customers over time. Therefore, a service that was primary introduced to build the brand no longer had the intended effect. A service manager described the situation as follows: 'It has a value for the customer when the customer pays for it, but to send 30 men on education free of charge, that has no value'. Basically, because a service given away has no value, the loyalty effect does not appear.

The introduction of a fee for educational services gave the service a higher status. When the service was free, many participants did not take the education serious. When the service got a fee, Bearing Ltd. improved the quality of the education and provided participants with a certificate to show the value of the education. In addition to being a profitable service, it regained its ability to improve the brand's image and create a loyalty effect for product sales. 


\section{Our new partner cannot work for free!}

Soundless Ltd. is a small supplier in the automotive industry that specialises in providing soundless environments in vehicles. Traditionally, the supplier participated in development projects with OEMs for free and was paid if or when an order was received. Given an increase in the amount of resources spent on development project for customers, Soundless Ltd. realised that it was giving away its competence for free and started a project to change its business model.

The key to get customers to start paying for previously free service was to cooperate with a consultancy firm. By bringing a key partner into the business relationship and extending the value proposition of the service, Soundless Ltd. was able to turn the service from free to fee. When the key partner was introduced into the business relationship, the customers accepted that these resources could not be used free. The marketing manager described the competence of the external partner as 'The consultant has so much more competence and larger resources, especially technical resources, than we do'. The introduction of a fee for the service had no effect on product sales. Most customers directly accepted the fee; however, major customers with power in the supply chain still want, and get, the service for free.

\section{We give you disproportional value!}

Mill Ltd. does not usually charge a fee for customised services created to solve specific customer problems. However, it has a strategy to create a reciprocal response from customers by providing disproportional value. Such customised services often build on an ability and willingness of the supplier to help the customer when unplanned incidents occur in the customer's business. In addition, the technical competence needed for such services includes the supplier's creativity and specialised expertise to solve problems and support customers' value creation processes. Mill 
Ltd. often include key partners as consulting firms or other customers to help the individual customer. The CEO of Mill Ltd. describes the strategy as: 'The idea is to provide a disproportionate value to the customer ... in relation to what you are actually charging him and you are reminding him that you are doing this. You can't be running out there every day doing this but I know how to pick the moments'.

The strategy can create an obligation of the customer and often leads to a reciprocal response to pay for the service provided, to pay the next time the service is used, or to pay for other services. Using this strategy can be seen as a parallel to the 'open up the wallet' strategy used in retailing to get the customer to start buying services.

\section{An analysis of transition strategies from free to fee}

The eight identified transition strategies from free to fee show how to change business model and involve specific changes of the business model, see Table III. In particular, we analyse degree and type of innovation, and how building blocks in the business model change. In our case studies we identify three degrees of business model innovation: (1) changes in the business model, (2) incremental business model innovation and (3) radical business model innovation. Except the revenue streams that are changed by the introduction of a fee, performing changes in the business model means that there is no or minor changes in the building blocks of the business model. Incremental business model innovation means changing the content and/or structure of the business model, while radical business model innovation concerns changing the governance of the business model. Our view of radical business model innovation focus on the change in a business relationship due to putting a fee on services and not changing the rules of all business on a market (see e.g. Treacy (2004)). 
First, a change in the business model is represented by the two cases 'Yesterday it was free - today it has a price!' and 'New Service - New Rules!'. These transition strategies represent two different approaches to change from free to fee either fast or slow. The business model can be changed from one day to another, just by starting to charge for something that has been free. Importantly, the effect is a reverse reciprocal response from customers with an immediate loss of service sales. Such a strategy can almost only be performed on capital equipment, for which highly specialised service personnel are needed. It is a common strategy in the pulp and paper industry, where a firm can provide services over a long product life cycle (Davidsson et al., 2009). In contrast, the 'New Service - New Rules!' only change the business model for new services. Thus, often the largest part of the service range is still provided for free through the product-based business model. If the life cycle of the product is long, this strategy will result in a gradual shift from free to fee that may take the life of a product generation to complete.

Incremental business model innovation is performed in the transition strategies 'We deliver a product AND a service!', 'The value of service!', 'You get what you pay for!' and 'We deliver a basic service AND extended services!'. These are examples, where the value proposition has been extended and/or there have been innovation in the content or structure of the business model. 'We deliver a product AND a service!', 'We deliver a basic service AND extended services!' and 'The value of service!' are based on innovating either the content or the structure of the service without altering the benefits of the value proposition. Much of the literature on service infusion suggest bundling as a strategy to succeed with services in a manufacturing firm (Baines et al., 2009), while our study suggest unbundling to as a strategy to perform incremental business model innovation. These strategies have no 
direct effect on the sales of existing services, but sales of the new version of the service for fee grow slowly. Significantly changing the basic service in 'You get what you pay for!' is needed to quickly create demand for the service without having to continue to provide the free service to create incentives for customers to buy the product.

Radical business model innovation appears through governance innovation and an extension of the value proposition in 'Our new partner cannot work for free!' and 'We give you disproportional value!'. 'We give you disproportional value!' is a highly customised service that specifically focuses on solving customer problems. In the studied case, this involved changes in both the demand and supply side of the business model, but due to the high degree of customization of the service, other cases can involve dramatic changes in other elements of the business model. To innovate through governance by including an external partner in the on-going business relationship represents a radical change of key partners, key activities, key resources and the value proposition. However, even such a strategy is not certain to succeed because the willingness to pay for services highly depends on the power in the supply chain. For small suppliers, uneven distribution of power can make the change from free to fee impossible.

- Insert Table III about here -

\section{Conclusions}

The research contributes to the literature on service infusion in manufacturing firms (Oliva and Kallenberg, 2003; Fang et al., 2008) and business model innovation (Osterwalder, 2004; Amit and Zott, 2012) by investigating strategies for transitioning from service for free to service for fee. Several studies have identified business model 
innovation as a key to perform service infusion profitably; but few studies have investigated the transition strategies manufacturing firms use to change the business model for services.

\section{Theoretical Implications}

The research presents different transition strategies that manufacturing firms use to change the business model for service from free to service for fee. The strategies are based on performing (1) changes in the business model, (2) incremental business model innovation, or (3) radical business model innovation.

Our empirical investigation suggests that there are different degrees of business model innovation and that manufacturing firms experience difficulties in changing the business model. Making minor changes in the business model in an ongoing business relationship is a difficult way to change from free to fee. However, when switching barriers are high, manufacturing firms with low competition can favourably use the strategy in combination with a stop of free service provision. The low risk strategy is to perform incremental business model innovation through minor changes in content and structure. Radical business model innovation involves changing the governance of the business model by including key partners in providing the value proposition (Zott and Amit, 2010). In the present study, the two most successful cases of changing the business model from free to fee concerns radical business model, which suggests that building the right value constellations for service provision is a key in changing the business model (Nenonen and Storbacka, 2010; Kowalkowski et al., 2013).

Setting up a separate service business is an important step when a manufacturing firm infuse services in their business, (Oliva and Kallenberg, 2003). The present research suggests transition strategies from free to fee to improve the 
turnover coming from the separate service business. Fang et al. (2008) show that service infusion does not have an effect on firm value until services reach a critical mass of 20-30 percent of turnover. Recently, Visnjic Kastalli and Van Looy (2013) extended these findings by showing that there is an U-shaped relationship between share of services and profitability. In addition, the present research identifies unbundling of services from both products and services as a key to build a service business (see e.g. Baines et al., 2009). Although researchers put an emphasis on bundling products and services in solutions, it seems that transition strategies from free to fee and unbundling of services are key ingredients in building a profitable service business.

The empirical investigation has certain limitations. One limitation is the extent of the study because the empirical study contains a limited number of cases. An explorative study of strategies was performed; therefore, extending the number of cases in future studies would be fruitful. In addition, the present study only concerns the suppliers' perspective on a change in business model. One additional extension of the study is to move from retrospective studies of changing from free to fee to longitudinal studies on how customers respond to different transition strategies. The present study investigates the change from free to fee, although this is an important change of business model there are more challenges facing manufacturing firms, such as 3D-printing and legislation on IPR for services that might demand radical business model innovation for whole markets and industries.

\section{Managerial implications}

Eight transition strategies for breaking free from free services were identified. These strategies provide alternatives for manufacturing firms that want to increase the range of services with a fee. Customers react differently towards the alternative strategies, 
and the short-term effect of 'Yesterday it was free - today it has a price!' can be devastating for a firm with scarce resources since it reduces existing product and service volumes. The most certain way to disengage from free services is 'Our new partner cannot work for free!', which is the transition strategy that has the least shortterm effects. Manufacturing firms often use strategies that create reverse reciprocity because the change is driven by necessity instead of as part of a deliberate strategy for becoming a solution provider.

Changing business model from free to fee includes several external problems, but internal problems can also hinder the change. There are at least two problems that firms must overcome to succeed with incremental or radical business model innovation. First, an existing business model that managers are familiar with feels safe, which may result in resistance to change (Gebauer et al., 2012). Second, the involvement of several departments within the manufacturing firm may lead to problems with cooperation and responsibilities. 


\section{References}

Amit, R., and Zott, C. (2012), “Creating value through business model innovation”, Sloan Management Review, Vol. 23 No. 3, pp. 41-49.

Baines, T., Lightfoot, H., Peppard, J., Johnson, M., Tiwari, A., Shehab, E., Swink, M. (2009), "Towards an operations strategy for product-centric servitization", International Journal of Operations \& Production Management, Vol. 29 No. 5, pp. 494-519

Brown, S., Gustafsson, A. and Witell, L. (2010), "Service logic: Transforming product-focused businesses", ASU Service Leadership Working Paper Series, No. 1.

Chesbrough, H. (2010), "Business model innovation: Opportunities and barriers", Long Range Planning, Vol. 43 No. 2-3, pp. 354-363.

Chesbrough, H. (2007), “Business model innovation: It's not just about technology anymore", Strategy and Leadership, Vol. 35 No. 6, pp. 12-17.

Davidsson, N., Edvardsson, B., Gustafsson, A. and Witell, L. (2009), "Degree of service-orientation in the pulp and paper industry", International Journal of Services Technology and Management, Vol. 11 No. 1, pp. 24-41.

Eisenhardt, K.E. (1989), "Building theories from case study research”, Academy of Management Review, Vol. 14 No. 4, pp. 532-550.

Eisenhardt, K.E. and Graebner, M.E. (2007), "Theory building from cases: Opportunities and challenges", Academy of Management Journal, Vol. 50 No. 1, pp. 25-32. 
Fang, E., Palmatier, R.W., Jan-Benedict E. and Steenkamp, M. (2008), "Effect of service transition strategies on firm value", Journal of Marketing, Vol. 72 No. 5, pp. 1-14.

Gebauer, H., Edvardsson, B., Gustafsson, A., and Witell, L. (2010), "Match or mismatch: Strategy-structure configurations in the service business of manufacturing companies", Journal of Service Research, Vol. 13 No. 2, pp. $198-215$.

Gebauer, H., Paiola, M. and Edvardsson, B. (2012), “A capability perspective on service business development in small and medium-sized suppliers", Scandinavian Journal of Management, Vol. 28 No. 4, pp. 321-339.

Grönroos, C. and Helle P. (2010), “Adopting a Service Logic in Manufacturing”, Journal of Service Management, Vol. 21 No. 5, pp. 564-590.

Gustafsson, A., Brax, S. and Witell, L. (2010), "Setting a research agenda for service business in manufacturing industries", Journal of Service Management, Vol. 21, No. 5, pp. 557-563.

Gustafsson, A., Kristensson, P. and Witell, L. (2012), "Customer co-creation in service innovation: a matter of communication?" Journal of Service Management, Vol. 23 No. 3, pp. 311-327.

Hsu, Y. (2011), "Design innovation and marketing strategy in successful product competition", Journal of Business \& Industrial Marketing, Vol. 26 No. 4, pp. $223-236$.

Kowalkowski, C., Witell, L. and Gustafsson, A. (2013), “Any way goes: Identifying value constellations for service infusion in SMEs", Industrial Marketing 
Management, Vol. 42 No. 1, pp. 18-30.

Krishnamurthy, C., Johansson, J., and Schlissberg, H. (2003), “Solutions selling: Is the pain worth the gain?" McKinsey Marketing Solutions, Vol. 1 No. 1, pp. 113.

Löfgren, M. (2005), "Winning at the first and second moments of truth: An exploratory study", Managing Service Quality, Vol. 15 No. 1, pp. 102-115.

Meredith, J. (1998), "Building operations management theory through case and field research", Journal of Operations Management, Vol. 16 No. 4, pp. 441-454.

Mitchell, D. and Coles, C. (2003), “The ultimate competitive advantage of continuing business model innovation", Journal of Business Strategy, Vol. 24 No. 5, pp. $15-21$.

Neely, A. (2008), "Exploring the financial consequences of the servitization of manufacturing", Operations Management Research, Vol. 1 No. 2, pp. 103118.

Nenonen, S. and Storbacka, K. (2010), "Business model design: conceptualizing networked value co-creation", International Journal of Quality and Service Sciences, Vol. 2 No. 1, pp. 43-59

Neu, W., and Brown, S. (2005), "Forming successful business-to-business services in goods-dominant firms", Journal of Service Research, Vol. 8 No. 1, pp. 3-17.

Oliva, R. and Kallenberg, R. (2003), "Managing the transition from products to services”, International Journal of Service Industry Management, Vol. 14 No. 2, pp. $160-172$.

Osterwalder, A. (2004), "The business model ontology: A proposition in a design 
science approach", Doctoral thesis, Présentée à l'Ecole des Hautes Etudes Commerciales de l'Université de Lausanne.

Osterwalder, A. and Pigneur, Y. (2010). Business Model Generation: A Handbook for Visionaries, Game Changers, and Challengers. John Wiley \& Sons, Inc., New Jersey.

Osterwalder, A., Pigneur, Y. and Tucci, C.L. (2005), "Clarifying business models: Origins, present, and future of the concept", Communications of the Association for Information Systems, Vol. 16 No. 1, pp. 1-25.

Ostrom, A.L., Bitner, M., Brown, S.W., Burkhard, K.A., Goul, M., Smith-Daniels, V., Demirkan, H. and Rabinovich, E. (2010), "Moving forward and making a difference: Research priorities for the science of service", Journal of Service Research, Vol. 13 No. 1, pp. 4-36.

Teece, D.J. (2010), “Business models, business strategy and innovation”, Long Range Planning, Vol. 43 No. 2-3, pp. 172-194.

Treacy, M. (2004), "Innovation as a last resort”, Harvard Business Review, Vol. 82 No. 7-8, pp. 29-30.

Tuli, K., Kohli, A. and Bharadwaj, S.G. (2007), "Rethinking Customer Solutions: From Product Bundles to Relational Processes", Journal of Marketing, Vol. 71 No. 3, pp. $1-17$.

Visnjic Kastalli, I. and van Looy, B. (2013), "Servitization: Disentangling the impact of service business model innovation on manufacturing firm performance", Journal of Operations Management, In press, http://dx.doi.org/10.1016/j.jom.2013.02.001. 
Wooden, S. and Baker, S. (2012), "Extracting key lessons in service innovation", Journal of Product Innovation Management, Vol. 29 No. 1, pp. 13-20.

Yin, R.K. (1994), Case Study Research - Design and Methods, SAGE Publications, London.

Zott, C. and Amit, R. (2010), "Business model design: An activity system perspective", Long Range Planning, Vol. 43 No. 2-3, pp. 216-226. 


\section{Tables}

Table I: Description of the participating manufacturing firms.

\begin{tabular}{|c|c|c|c|c|}
\hline Firm & $\begin{array}{l}\text { No. of } \\
\text { Employees }\end{array}$ & Examples on Services & Basic product offering & $\begin{array}{l}\text { Services that moved } \\
\text { from free to fee }\end{array}$ \\
\hline $\begin{array}{l}\text { Soundless } \\
\text { Ltd. }\end{array}$ & 22 & $\begin{array}{l}\text { Noise-reducing } \\
\text { solutions, acoustic } \\
\text { calculations, technical } \\
\text { reports }\end{array}$ & $\begin{array}{l}\text { Noise control materials } \\
\text { and products }\end{array}$ & (a) Noise consulting \\
\hline Mill Ltd. & 120 & $\begin{array}{l}\text { Maintenance } \\
\text { outsourcing and on-site } \\
\text { services }\end{array}$ & $\begin{array}{l}\text { Components and spare } \\
\text { parts to rolls and other } \\
\text { equipment }\end{array}$ & $\begin{array}{l}\text { (a) The entire range of } \\
\text { services } \\
\text { (b) Problem solving }\end{array}$ \\
\hline Vehicle Ltd. & 475 & Systems for vehicles & $\begin{array}{l}\text { Vehicles for the transport } \\
\text { industry. }\end{array}$ & $\begin{array}{l}\text { (a) Training services } \\
\text { (b) e-services }\end{array}$ \\
\hline Pulp Ltd. & 155 & $\begin{array}{l}\text { Basic service, } \\
\text { optimisation and } \\
\text { improvement services }\end{array}$ & $\begin{array}{l}\text { Equipment for the Pulp } \\
\text { and Paper industry. }\end{array}$ & $\begin{array}{l}\text { (a) Renovation of } \\
\text { machinery }\end{array}$ \\
\hline Bearing Ltd. & 3500 & $\begin{array}{l}\text { Basic service, } \\
\text { optimisation services, } \\
\text { outsourcing }\end{array}$ & Bearings & (a) Education services \\
\hline Drink Ltd. & 300 & $\begin{array}{l}\text { Basic service, } \\
\text { education, economic } \\
\text { analysis. }\end{array}$ & A drink & (a) Range of services \\
\hline
\end{tabular}


Table II: A description of the transition strategies from free to fee service.

\begin{tabular}{|c|c|c|c|}
\hline Strategy & Description & Effect & $\begin{array}{l}\text { Case } \\
\text { Firm }\end{array}$ \\
\hline $\begin{array}{l}\text { Yesterday it was } \\
\text { free - today it has a } \\
\text { price! }\end{array}$ & $\begin{array}{l}\text { Change the business model of a } \\
\text { service from one day to another } \\
\text { - one day free, the next day with } \\
\text { a fee. }\end{array}$ & $\begin{array}{l}\text { Major loss in sales of repairs } \\
\text { and spare parts, then a slow } \\
\text { recovery with increasing sales } \\
\text { of service. }\end{array}$ & Mill \\
\hline $\begin{array}{l}\text { New service - new } \\
\text { rules! }\end{array}$ & $\begin{array}{l}\text { Introduce a fee on for all new } \\
\text { services, but keep the old } \\
\text { services free. }\end{array}$ & $\begin{array}{l}\text { No effect on product sales, } \\
\text { spare parts and repair. A slow } \\
\text { increase in sales of the new } \\
\text { service. }\end{array}$ & $\begin{array}{l}\text { Vehicle } \\
\text { Ltd. }\end{array}$ \\
\hline $\begin{array}{l}\text { The value of } \\
\text { service! }\end{array}$ & $\begin{array}{l}\text { Start showing customers the } \\
\text { value of service, and then } \\
\text { introduce ways to get a fee for } \\
\text { the co-created value. }\end{array}$ & $\begin{array}{l}\text { Introduce the fee stepwise by } \\
\text { showing its financial value on } \\
\text { the bill. When customers get } \\
\text { accustomed to it, start with the } \\
\text { fee. }\end{array}$ & $\begin{array}{l}\text { Vehicle } \\
\text { Ltd. }\end{array}$ \\
\hline $\begin{array}{l}\text { We deliver a } \\
\text { product AND a } \\
\text { service! }\end{array}$ & $\begin{array}{l}\text { The offering includes a product } \\
\text { and a service, where the service } \\
\text { is unbundled from the offering. }\end{array}$ & $\begin{array}{l}\text { Continued sales of the product } \\
\text { and no sales of services. } \\
\text { Services are still given away } \\
\text { for free to }\end{array}$ & $\begin{array}{l}\text { Drink } \\
\text { Ltd., }\end{array}$ \\
\hline $\begin{array}{l}\text { We deliver a basic } \\
\text { service AND } \\
\text { extended services! }\end{array}$ & $\begin{array}{l}\text { The service includes several } \\
\text { services that now are unbundled. } \\
\text { Basic service for free or a small } \\
\text { fee. If more services are needed, } \\
\text { they cost extra. }\end{array}$ & $\begin{array}{l}\text { Start with basic services and } \\
\text { no sales of extra services. } \\
\text { Then, the extra services start } \\
\text { to sell. }\end{array}$ & Pulp Ltd. \\
\hline $\begin{array}{l}\text { You get what you } \\
\text { pay for! }\end{array}$ & $\begin{array}{l}\text { A service given away has no } \\
\text { value; therefore, the loyalty } \\
\text { effect does not appear. Its price } \\
\text { gives the service the status it } \\
\text { deserves. }\end{array}$ & $\begin{array}{l}\text { The service gets a higher } \\
\text { status and demand for the } \\
\text { service increases. }\end{array}$ & $\begin{array}{l}\text { Bearing } \\
\text { Ltd. }\end{array}$ \\
\hline $\begin{array}{l}\text { Our new partner } \\
\text { cannot work for } \\
\text { free! }\end{array}$ & $\begin{array}{l}\text { Start delivering a new improved } \\
\text { service together with a partner } \\
\text { that replaces the old service. } \\
\text { Introduce a fee at introduction. }\end{array}$ & $\begin{array}{l}\text { No effect on product sales. } \\
\text { Most customers directly } \\
\text { accept the fee. Major } \\
\text { customers with power in the } \\
\text { supply chain want the new } \\
\text { service for free. }\end{array}$ & $\begin{array}{l}\text { Soundless } \\
\text { Ltd. }\end{array}$ \\
\hline $\begin{array}{l}\text { We give you } \\
\text { disproportional } \\
\text { value! }\end{array}$ & $\begin{array}{l}\text { The service has great value for } \\
\text { the customer, which creates an } \\
\text { obligation for the customer to } \\
\text { pay. }\end{array}$ & $\begin{array}{l}\text { Create an obligation to pay. In } \\
\text { some cases, customers paid } \\
\text { even if the deal was free } \\
\text { services for customers. }\end{array}$ & Mill Ltd. \\
\hline
\end{tabular}


Table III: What is innovative in the transition strategies from free to fee.

\begin{tabular}{|c|c|c|c|}
\hline Transition strategy & Degree of innovation & Type of innovation & Main change(s) in BMC \\
\hline $\begin{array}{l}\text { Yesterday it was free } \\
\text { today it has a price }\end{array}$ & $\begin{array}{l}\text { Change in business } \\
\text { model }\end{array}$ & & Revenue streams \\
\hline $\begin{array}{l}\text { New service - new } \\
\text { rules! }\end{array}$ & $\begin{array}{l}\text { Change in business } \\
\text { model }\end{array}$ & & Value proposition \\
\hline The value of service! & $\begin{array}{l}\text { Incremental business } \\
\text { model innovation }\end{array}$ & Content & Revenue streams \\
\hline $\begin{array}{l}\text { We deliver a product } \\
\text { AND a service! }\end{array}$ & $\begin{array}{l}\text { Incremental business } \\
\text { model innovation }\end{array}$ & Structure & $\begin{array}{l}\text { Value proposition \& } \\
\text { Revenue streams }\end{array}$ \\
\hline $\begin{array}{l}\text { We deliver a basic } \\
\text { service AND extended } \\
\text { services! }\end{array}$ & $\begin{array}{l}\text { Incremental business } \\
\text { model innovation }\end{array}$ & Structure & $\begin{array}{l}\text { Value proposition \& } \\
\text { Revenue streams }\end{array}$ \\
\hline $\begin{array}{l}\text { You get what you pay } \\
\text { for! }\end{array}$ & $\begin{array}{l}\text { Incremental business } \\
\text { model innovation }\end{array}$ & Structure & Value proposition \\
\hline $\begin{array}{l}\text { Our new partner } \\
\text { cannot work for free }\end{array}$ & $\begin{array}{l}\text { Radical business } \\
\text { innovation }\end{array}$ & $\begin{array}{l}\text { Governance \& } \\
\text { Structure }\end{array}$ & $\begin{array}{l}\text { Revenue streams \& Key } \\
\text { partner }\end{array}$ \\
\hline $\begin{array}{l}\text { We give you } \\
\text { disproportional value! }\end{array}$ & $\begin{array}{l}\text { Radical business } \\
\text { innovation }\end{array}$ & Governance & $\begin{array}{l}\text { Value proposition \& Key } \\
\text { partner }\end{array}$ \\
\hline
\end{tabular}

